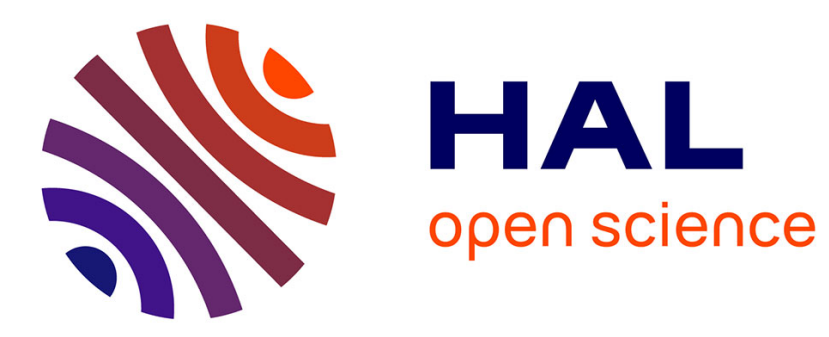

\title{
Optimization of peptide-plasmid DNA vectors formulation for gene delivery in cancer therapy exploring design of experiments
}

Ângela Sousa, Ana Almeida, Rúben Faria, Karidia Konate, Prisca Boisguérin, João Queiroz, Diana Costa

\section{To cite this version:}

Ângela Sousa, Ana Almeida, Rúben Faria, Karidia Konate, Prisca Boisguérin, et al.. Optimization of peptide-plasmid DNA vectors formulation for gene delivery in cancer therapy exploring design of experiments. Colloids and Surfaces B: Biointerfaces, 2019, 183, pp.110417. 10.1016/j.colsurfb.2019.110417 . hal-02339026

\section{HAL Id: hal-02339026 \\ https://hal.umontpellier.fr/hal-02339026}

Submitted on 15 Dec 2020

HAL is a multi-disciplinary open access archive for the deposit and dissemination of scientific research documents, whether they are published or not. The documents may come from teaching and research institutions in France or abroad, or from public or private research centers.
L'archive ouverte pluridisciplinaire HAL, est destinée au dépôt et à la diffusion de documents scientifiques de niveau recherche, publiés ou non, émanant des établissements d'enseignement et de recherche français ou étrangers, des laboratoires publics ou privés. 
1 Optimization of peptide-plasmid DNA vectors formulation for gene delivery

2 in cancer therapy exploring design of experiments

3

4

5 Ângela Sousa ${ }^{1}$, Ana M. Almeida ${ }^{1}$, Rúben Faria ${ }^{1}$, Karidia Konate ${ }^{2}$ Prisca Boisguerin ${ }^{2}$, 6 João A. Queiroz ${ }^{1}$ and Diana Costa ${ }^{1 *}$

7

8

$9 \quad{ }^{1}$ CICS-UBI - Centro de Investigação em Ciências da Saúde, Universidade da Beira

Interior, Av. Infante D. Henrique, 6200-506 Covilhã, Portugal

${ }^{2}$ Centre de Recherche en Biologie cellulaire de Montpellier, CNRS UMR 5237, Université de Montpellier, 1919 Route de Mende, 34293 Montpellier Cedex 5, France

*corresponding author:

Diana Costa

E-mail address: dcosta@fcsaude.ubi.pt

Postal address: Centro de Investigação em Ciências da Saúde, Universidade da Beira Interior, Av. Infante D. Henrique, 6200-506 Covilhã, Portugal

Number of words: 5.880

Number of Figures: 3

Number of tables: 6 


\section{Abstract}

2

3

The field of gene therapy still attracts great interest due to its potential therapeutic effect towards the most deadly diseases, such as cancer. For cancer gene therapy to be feasible and viable in a clinical setting, the design and development of a suitable gene delivery system is imperative. Peptide based vectors, in particular, reveal to be promising for therapeutic gene release. Following this, two different peptides, RALA and WRAP5, have been investigated mainly regarding their ability to form complexes with a p53 encoding plasmid (pDNA) with suitable properties for gene delivery. To address this issue, and after an initial screening study focused on the dependence of pDNA complexation capacity with the nitrogen to phosphate groups (N/P) ratio, a design of experiments (DoE) tool has been employed. For each peptide/pDNA system, parameters such as, the buffer $\mathrm{pH}$ and the N/P ratio were considered the DoE inputs and the vector size, zeta potential and pDNA complexation capacity (CC) were monitored as DoE outputs. The main goal was to find the optimal experimental conditions to minimize particle sizes, as well as, to maximize the positive surface charges of the formulated nanosystems and maximize the pDNA CC. Through the DoE method applied, the optimal RALA/pDNA and WRAP5/pDNA formulations were revealed and show interesting features related to peptide structure and pDNA complexation ability. This work illustrates the great utility of experimental design tools in optimizing the formulation of peptide/pDNA vectors in a minimum number of experiments providing relevant knowledge for the development of more suitable and efficient gene delivery systems. The new insights achieved on these carriers clearly instigate deeper research on gene therapy. 
1 The field of gene therapy is still a contemporary research subject with great impact in the 2 evolution of technological and biomedical areas. ${ }^{1,2}$ The possible correction of genetic 3 diseases by insertion of a functional gene may significantly contribute for advances in the 4 treatment of the most serious and deadly diseases. ${ }^{2-6}$ Among the wide range of possible 5 clinical applications, cancer therapy emerges as one of the most challenging and 6 promising. ${ }^{2-4,7,8}$ For the success of gene therapy protocols, the conception of an adequate 7 and high-performance gene delivery system is essential. Beyond the higher transfection 8 efficiency achieved with viral vectors, their immunogenicity, toxicity and possible random mutagenesis compromise their use in gene delivery, highlighting the safety and assets of non-viral systems. ${ }^{9}$ Synthetic formulations are, in general, easy to produce and to manipulate, biocompatible with different biological systems due to reduced pathogenicity and they can load/encapsulate a large amount of genetic content. ${ }^{2-4}$ In the last decade, an enormous variety of non-viral vectors has been conceived and engineered to exhibit controlled/tailored properties to meet the vast demands of gene therapy protocols. Liposomes, polyplexes, micelleplexes, dendrimers, hydrogels, inorganic nanoparticles and peptide based systems revealed to be promising for therapeutic gene release. ${ }^{3,8,10-15}$ Peptides, in particular, offer a set of reliable characteristics, such as, their biocompatibility and biodegradability in vivo, the amphipathic or cationic structure, along with the possibility of being tailored, that make them very convenient to condense pDNA forming nanoparticles able of cell uptake, internalization and gene expression. ${ }^{15,16-18}$ Additionally, the rational peptide design, accounting for both key structural features and interactions, increments the potential of their use in the formulation of advanced and highperformance peptide delivery systems for therapeutic applications. ${ }^{1,15,19-27}$ Furthermore, peptides can perform multiple functions (cell permeability, targeting, endosome disruption or nuclear localization) and surpass many biological barriers enhancing the gene delivery mechanism..$^{20,21,23,26,27}$ Beyond the intrinsic peptide properties, the peptide/nucleic acids carrier must possess an adequate size $(\leq 200 \mathrm{~nm})$ for cellular uptake and internalization, a positive surface charge to enhance the interaction with the negatively charged proteoglycans present in the cellular membrane, and it should also ensure an efficiently complexation of genetic cargo. ${ }^{28,29}$ Following this, finding the ideal peptide/payload system, that meets all the mentioned requirements, can be challenging, costly and a time-consuming task involving waste of resources. In this context, design of experiments (DoE) can be applied to optimize the formulation step in order to obtain the most convenient vectors for in vitro transfection. Pursuing this goal, in the current work, 
1 Composite Central Face design (CCF) was used to explore and optimize the development

2 of suitable complexes based on peptide (RALA or WRAP5) and p53 encoding plasmid

3 DNA (pDNA). The DoE tool enables to systematically and simultaneously vary and

4 combine several parameters to get a deeper knowledge on the peptide/pDNA

5 complexation process with few experiments when compared to random experiment

6 approach. ${ }^{30-32}$ Likewise, this statistical tool can predict the ideal conjugation of inputs to

7 optimize the responses and, therefore, find the set of conditions correspondent to lower

8 sized particles possessing the maximum positive surface charges and highest pDNA

9 complexation capacity. From this optimization, we may greatly expect that the "ideal"

10 RALA/pDNA and WRAP5/pDNA vectors can be found. This will, for sure, promote

11 further research aiming to explore their suitability as potential gene delivery systems.

Materials and Methods

27 Materials.

The

RALA

peptide

$\left(\mathrm{NH}_{2}-\right.$

28 WEARLARALARALARHLARALARALRACEA-COOH $)^{14}$ was synthesized by solid- 
1 state synthesis (fluorenylmethyloxycarbonyl, FMOC, Biomatik, USA) and supplied as a 2 lyophilized powder. WRAP5 ${ }^{15}\left(\mathrm{NH}_{2}\right.$-LLRLLRWWWRLLRLL-CONH 2$)$ synthesis was 3 performed on a LibertyBlue ${ }^{\mathrm{TM}}$ Microwave Peptide Synthesizer (CEM Corporation, NC, 4 USA) with an additional Discover ${ }^{\mathrm{TM}}$ module (CEM Corporation, NC, USA) combining 5 microwave energy at $2450 \mathrm{MHz}$ to the Fmoc/tert-butyl (tBu) strategy. Peptide identity 6 and purity was checked by LC-MS (Waters, France). RALA stock solutions were 7 prepared in ultrapure water and aliquots were stored at $-20{ }^{\circ} \mathrm{C}$, according to manufacturer's instructions. WRAP5 stock solutions were stored at $4{ }^{\circ} \mathrm{C}$. The $6.07 \mathrm{kbp}$ plasmid pcDNA3-FLAG-p53 (Addgene plasmid 10838, USA) used in the experiments was produced and purified by a procedure developed by our research group and described in the literature. ${ }^{4}$ The $6.56 \mathrm{kbp}$ plasmid pGL3 luciferase reporter vector was kindly provided by Dr. Franck Couillaud (Bordeaux University, France). All solutions were freshly prepared using Millipore-Q water (Billerica, USA).

Preparation of peptide-pDNA complexes. pDNA stock solutions $(100 \mu \mathrm{g} / \mathrm{mL}$ for RALA/pDNA complexes and $5 \mu \mathrm{g} / \mathrm{mL}$ for WRAP5/pDNA complexes) were prepared in Tris buffer (10 mM, pH 8), while RALA and WRAP5 peptides were dissolved in Tris buffer (10mM, pH 6, 7 or 8) immediately before use. Variable concentrations of peptides $(40 \mu \mathrm{L})$ were added (vortexed for $60 \mathrm{~s}$, drop by drop every $10 \mathrm{~s}$ ) to a fixed volume of pDNA $(10 \mu \mathrm{L})$ to formulate peptide/pDNA complexes at charge ratios (positive charges of peptide to negative charges of pDNA, N/P) of $0.1,0.5,1,1.5,2,3,5$ and 10 . The mixture was incubated for $30 \mathrm{~min}$ at room temperature. The complexes were centrifuged at $11,000 \mathrm{~g}$ for $20 \mathrm{~min}$ and the pellet contained the pDNA based nanoparticles. The amount of non-bound pDNA was determined spectrophotometrically measuring the absorbance of the supernatant at $260 \mathrm{~nm}$ using a NanoPhotometer ${ }^{\mathrm{TM}}$ (Implen, Inc; CA, USA). The pDNA complexation capacity was obtained from the equation:

$\mathrm{CC}(\%)=[(\mathrm{pDNA}) \mathrm{T}-(\mathrm{pDNA}) \mathrm{F} /(\mathrm{pDNA}) \mathrm{T}] \times 100$

where (pDNA)T stands for the total amount of pDNA and (pDNA)F is the non-bound fraction of pDNA found free in the supernatant.

Agarose gel immobilization assay. Agarose gel electrophoresis was performed to evaluate the complexation of pDNA into the various developed complexes. The electrophoresis was carried out using a gel with $1 \%$ agarose and $1 \mu \mathrm{g} / \mathrm{mL}$ GreenSafe 
1 Premium (NZYTech, Portugal) and it was run at $150 \mathrm{~V}$ for $30 \mathrm{~min}$ in TAE buffer (40 mM

2 Tris base, $20 \mathrm{mM}$ acetic acid and $1 \mathrm{mM}$ EDTA, $\mathrm{pH}$ 8.0). The gel visualization was made

3 in UVItec Gel documentation system under UV light (UVItec Limited, United Kingdom).

4 Determination of size and surface charges. The average particle size and the zeta 5 potential of pDNA vectors have been determined by Dynamic Light Scattering (DLS), at $6 \quad 25^{\circ} \mathrm{C}$, using a Zetasizer nano ZS. The pellet containing the complexes was suspended in 7 deionized water. For data analysis, dispersant viscosity and refractive index are considered the same as those for pure water at $25{ }^{\circ} \mathrm{C}$ : $0.8905 \mathrm{mPa} \mathrm{s}^{-1}$ and 1.333 , respectively. Dynamic light scattering (DLS) using a He-Ne laser $633 \mathrm{~nm}$ with noninvasive backscatter optics (NIBS) and electrophoretic light scattering using M3-PALS laser technique (Phase analysis Light Scattering) were applied for particles size and charge investigation, respectively. The Malvern zetasizer software v 6.34 was used.

Design of experiments. To optimize the formulation of peptide/pDNA vectors minimizing the size of the particles and maximize both positive surface charges and pDNA CC, a CCF design was applied. Regarding this, the buffer $\mathrm{pH}$ and N/P ratio factors were considered as DoE inputs. The inputs were studied at three levels $(-1 ; 0 ;+1)$ and the range was defined from a preliminary screening study. The vectors size, zeta potential and pDNA CC parameters were the evaluated responses (outputs); the particles size was minimized and both the positive surface charges and pDNA CC maximized. Statistical analysis was performed through the use of Design-Expert version 11. The generalized second-order polynomial model equation used in the response surface analysis is presented below (Equation (2)):

$$
\mathrm{Y}=\beta_{0}+\beta_{1} X_{1}+\beta_{2} X_{2}+\beta_{11} X_{1}^{2}+\beta_{22} X_{2}^{2}+\beta_{12} X_{1} X_{2}
$$

\section{Results and Discussion}

Formation of peptide/pDNA Complexes. Studies from the literature on the interaction of cell-penetrating cationic and amphipathic peptides with negatively charged oligonucleotides or nucleic acids are, in general, consistent with a strong electrostatic attraction, along with hydrophobic interactions, leading to the formation of 
1 nanoparticles. ${ }^{14-16,20-27}$ Furthermore, it was found that the N/P ratio parameter exhibits a dominant role in the complexation profile with, in most of the cases, a higher N/P ratio favoring the formation of complexes and enhancing their properties. ${ }^{14-16,33}$ Based on this knowledge, in the current work, the cell penetrating peptides RALA and WRAP5 have been considered to condense pDNA. RALA, a 30mer arginine-rich peptide, contains one tryptophan and 7 arginine residues and has an alpha helical structure containing both hydrophobic and hydrophilic amino acids ${ }^{34}$ and WRAP5, a 15mer tryptophan and arginine rich amphipatic peptide, with 4 arginine and 3 tryptophan residues clustered in the primary peptide sequence, being this tryptophan-rich motif identified as a membrane penetrating domain. It is also known, from an in silico prediction of 3D structure and circular dichroism, that WRAP5 adopted $\alpha$-helical structure. ${ }^{15}$ The interaction between RALA or WRAP5 and pDNA has been explored at various N/P ratios, with the aim to reveal the pDNA condensation profile and its dependence on N/P ratio. To access this information, the conception of RALA/pDNA or WRAP5/pDNA was investigated by agarose gel electrophoresis. A summary of the study is represented in Figure 1. From this experiment and for all systems considered, it can be observed that pDNA alone freely migrate into the agarose gel. The interaction between WRAP5 and pGL3 plasmid shows that the complexation can lead to the immobilization of pDNA in a charge-dependent manner; pDNA was completely immobilized from N/P ratio of 1 (Figure 1A). Supported by this information, the condensation of p53 plasmid by WRAP5 has been researched and an efficiently complexation was also found for complexes formulated at N/P $\geq 1$ (Figure 1B). Contrary, RALA does not ensure complete immobilization of p53 plasmid at N/P ratio of 1 . For N/P ratios from 0.1 to 1 , the charge of pDNA is not sufficiently neutralized, by RALA, to allow the complex to remain in the wells. This achievement only can be observed from N/P ratio of 2 onward, as represented in Figure 1C; despite the fact that RALA has 7 arginine residues while WRAP5 has only four of them. These results already predict some differences, between the two peptides, concerning the ability to condense and encapsulate pDNA which can be related with their cationic nature, as well as, to conformational changes induced by the presence of pDNA, what dictates the strength of interaction. This subject will be deeply discussed later on in this report. The preliminary agarose gel shift analysis allows for the definition of the appropriate N/P ratio range for the inputs (starting points) when applying the CCF model of DoE. Furthermore, as both peptides contain amino acids (mainly arginine and tryptophan) susceptible to $\mathrm{pH}$ variations, what may lead to both structural and conformational changes, the effect of 
1 buffer $\mathrm{pH}$ on pDNA CC has been evaluated in a preliminary study. Different buffer $\mathrm{pH}$

2 values were considered at peptide/pDNA complexes formulation step and the pDNA CC

3 has been determined and the pDNA immobilization investigated by agarose gel

4 electrophoresis. The obtained results are consistent with a variation on the peptide ability for pDNA complexation with $\mathrm{pH}$ (data not shown). From this study, buffer $\mathrm{pH}$ was selected as DoE input and the respective range was defined accordingly.

Model generation and statistical analysis. To achieve the ultimate parameter conjugation that would allow the optimal nanoparticle formulation, a three-level CCF design was applied. In Table 1 is presented the suggested coded combination of levels. These coded levels represent the minimum range limit $(-1)$, the maximum range limit $(+1)$ and the average of both (0). According to preliminary studies, buffer $\mathrm{pH}$ range was set to 6-8 for both peptides and N/P ratio range was set to 1-5 for RALA and 1-3 for WRAP5. Critical parameters such as nanoparticle size, zeta potential and complexation capacity (CC) were chosen as DoE outputs due to their impact on nanoparticle formulation during the development of novel gene delivery systems. ${ }^{29,35}$ First, size and zeta potential are known to directly affect the ability of the nanoparticles to effectively enter the cell. Smaller nanoparticle sizes facilitate cell entry while positive zeta potential favour the interaction between the carriers and the negatively charged cell membrane. ${ }^{28,29}$ On the other hand, $\mathrm{CC}$ allows to determine if the nanoparticle formulation process is rendering a good yield of encapsulated pDNA. It is crucial to ensure that no considerable amount of pDNA is lost throughout the formulation process, so that desirable therapeutic levels can be achieved in a profitable process. In Table 2 are portrayed all runs performed for both peptides, with the real value combination for each input coupled with the data for each output. The data concerning size and zeta potential has been obtained through DLS measurements while pDNA CC has been determined by the procedure described in the experimental section. Three central points, marked at grey, were tested in the same conditions to access the model reproducibility (runs 2, 4 and 6 for RALA and 1, 9 and 11 for WRAP5). After performing all experiments proposed by the CCF design and evaluating the chosen outputs, statistical analysis was performed by Design-Expert software. In Table 3 are shown the statistical coefficients obtained for the output of each peptide, which are used to understand if the statistical models generated from these experiments are valid and fit the data. Thus, $\mathrm{R}^{2}$ represents the coefficient of determination, providing information regarding the fitness of the output statistical model 
1 to the data. ${ }^{31}$ This should vary between 0 and 1 , ideally reaching 1 . As perceivable in Table

23 , all outputs present a $\mathrm{R}^{2}$ very close to 1 , suggesting all models fit the data. Adjusted $\mathrm{R}^{2}$ represents if the theoretical values adjust to the experimental data. If adjusted $\mathrm{R}^{2}$ is much lower than its $\mathrm{R}^{2}$, sample size might not be adequate to the model. ${ }^{36,37}$ As can be consulted in Table 3, all outputs present a valid adjusted $\mathrm{R}^{2}$, never lowering more than 0.035 comparatively to its $\mathrm{R}^{2}$. On the other hand, predicted $\mathrm{R}^{2}$ provides information concerning the suitability of the model in predicting new data. The higher $\mathrm{R}^{2}$, the more useful the statistical model is in predicting new data. As can be observed in Table 3, all models present high predicted $\mathrm{R}^{2}$ values $(>0.76)$, thus highlighting the predictive power of these models. Finally, adequate precision allows the measurement of the signal to noise ratio. It should be higher than 4 in order to indicate an adequate signal. In Table 3 it is possible to verify that all models have an adequate precision $>16$, thus indicating that these models provide an appropriate signal. The overall study of all these coefficients shows that the chosen quadratic model was suitable for the statistical analysis of these outputs. To further prove the validity of the DoE, ANOVA analysis was performed. In Table 4 is represented the model significance for each output, coupled with the corresponding lack of fit. A good valid model must present a significant value for its model (p-value $<0.05$ ) and a nonsignificant value for its lack of fit (p-value >0.05), thus suggesting the model data is significant and it fits. ${ }^{38}$ As observed in Table 4, all output models are significant and do not present a significant lack of fit. Thus, it can be confirmed that a good and valid statistical model was achieved for all outputs in both peptides.

Input interaction effects on nanoparticle size, zeta potential and $C \boldsymbol{C}$. To evaluate the main effects that the input factors present towards the outputs, a coded multiple regression equation can be generated by Design-Expert software. In this equation, the value of each factor (positive or negative) indicates a positive or negative effect in the response, respectively. In Table 5 is presented the equation of each output for both peptide-based systems, where A represents factor N/P ratio and factor $\mathrm{B}$ represents buffer $\mathrm{pH}$. It is generally perceivable that N/P ratio has a negative effect in size outputs for both peptides. This is explained by the fact that to a higher N/P ratio corresponds an increased amount of amine groups and, therefore, positive charges that enhance the electrostatic interaction with pDNA phosphate groups. This seems to originate a higher degree of pDNA condensation inside the peptides, thus resulting in complexes with smaller sizes. ${ }^{39}$ On the other hand, N/P ratio has a positive effect in both zeta potential and CC for RALA and 
1 WRAP5 vectors. This behavior can be related to the increment in the amine groups, that contribute to higher positive surface charge, thus increasing the zeta potential, and enhance the complexation of negatively charged pDNA through electrostatic interaction with the phosphate chain. ${ }^{39}$ Moreover, buffer $\mathrm{pH}$ has a positive effect in size output, while both zeta potential and $\mathrm{CC}$ are negatively affected by $\mathrm{pH}$. These facts are most probably related with the ionization profile exhibited by the constituent residues of the peptides. Although still intriguing fact, it is well known that arginine has the remarkable ability to keep its cationic charge in neutral, acidic and most basic environments. ${ }^{40,41}$ Several factors can contribute for this unusual behavior, such as, the positive and delocalized charge of guanidinium moiety along with its low hydration energy; the conformational flexibility of arginine long side chain and its high intrinsic pKa value estimated to be $\sim 13.8 .^{41}$ Therefore, arginine can remain cationic even in the nonpolar hydrophobic core of a peptide. ${ }^{42}$ Contrary situation is verified for other residues like lysine, leucine, histidine or glutamic acid, as their charge can dramatically change with environmental $\mathrm{pH}$. RALA and WRAP5, as peptides rich in arginine residues, can benefit from the capacity of this amino acid to be positively charged at most physiological conditions. However, the variation of protonation trend with buffer $\mathrm{pH}$ of other residues in the peptide sequence may also play a role, indeed a minor one but, certainly, not negligible. In general, as $\mathrm{pH}$ increases less protonated the residues become and in some situations, depending on internal positions into the peptide, the residues may shift their $\mathrm{pKa}$ values to neutral state. Lysines, for instance, may present pKa values below $6 .{ }^{43}$ In this work, we hypothesize that the low protonation of residues than arginine conferred less cationic character to peptides what weakens the interaction between RALA or WRAP5 with the negatively charged pDNA. To support this assumption, the net charge of each peptide at different $\mathrm{pH}$ values considered has been evaluated based on the calculation from different website (Bachem, Peptide Calculator and Novoprolabs). The obtained data can be consulted in Table S1 (available in the Supplementary Material). In general and for RALA, it indicates a decrease in peptide net charge by increasing buffer $\mathrm{pH}$. No differences with $\mathrm{pH}$ were found for WRAP5. This in turn results in less compact nanoparticles with higher sizes. ${ }^{32}$ Furthermore, the low protonation at high buffer $\mathrm{pH}$ leads to less positive charges, thus decreasing the surface charge of the nanoparticles and, consequently, lowering zeta potential values. The fact that less positive charges are available also weakens the interaction with pDNA, thus affecting its complexation capacity. Additionally, we also believe that variation in buffer $\mathrm{pH}$ can induce conformational changes in the peptides that 
1 influence their interaction with pDNA phosphate groups, with direct consequences in the 2 properties exhibited by the resulting nano-complexes. A circular dichroism (CD) study 3 performed by McCarthy et al. on RALA peptide presents an increased $\alpha$-helicity at a lower $\mathrm{pH} .{ }^{44}$ Moreover, a CD experiment for WRAP5 at different $\mathrm{pH}$ values considered, available in the Supplementary Material (Figure S1), shows a more pronounced helical configuration at $\mathrm{pH} 7$ compared to the one found at $\mathrm{pH} 6$ or $\mathrm{pH}$. The slight conformational changes are characterized by an isodichroic point at $203.5 \mathrm{~nm}$.

Furthermore, the multiple regression equations can be depicted by three-dimensional surface plots for each output. The different color intensity represents the range for optimal points, being the largest interaction identified by red. Likewise, the ellipticity obtained in surface plots is indicative of the interaction order that occurs between the chosen factors and the respective output. ${ }^{45}$ As it is presented in Figure 2, all surface plots present red areas and a very convex surface, thus suggesting all inputs have a strong interaction towards each output. In addition, the downward-facing concavity indicates that N/P ratio and $\mathrm{pH}$ factors have a negative effect on the size response, because the higher these inputs the smaller the size of the nanoparticles, while the upward-facing concavity suggests a positive effect of the inputs on the zeta potential and $\mathrm{CC}$ responses, as it was discussed for the multiple regression equations (Table 5).

Outputs optimization and model validation. After validating statistical models and understanding the effect each factor presents towards each input, an optimal point aiming size minimization and zeta potential and CC maximization was calculated. Design-expert software suggested the inputs combination of N/P ratio of 5 and buffer $\mathrm{pH}$ of 6.6 for RALA nanoparticles optimization, while a N/P ratio of 3 with a buffer $\mathrm{pH}$ of 7.0 for WRAP5. The predicted outputs for these optimal points as well as the respective confidence interval (95\%) are identified in Table 6. Both experiments were performed in triplicate and the resulting outputs were validated according to the data expected by Design-Expert software. For RALA peptide, optimal point provided a size of $183.8 \mathrm{~nm}$, a zeta potential of $+32.7 \mathrm{mV}$ and a $\mathrm{CC}$ of $92.7 \%$. On the other hand, WRAP5 optimal point demonstrated a size of $103 \mathrm{~nm}$, a zeta potential of $+33.57 \mathrm{mV}$ and a CC of $89.5 \%$. Both optimal points were found to be within the confidence interval provided by the Design-Expert software where the outputs are considered valid (Table 6). A comparison between two peptide/pDNA systems mainly highlights the lower N/P ratio required for WRAP5/pDNA vectors to achieve a lower size, positively high surface charges and a 
1 pDNA CC around 90\%. Following this, it seems that WRAP5 interacts more strongly

2 with pDNA causing its condensation in the presence of lower amine positive charges. The

3 WRAP5 tryptophan cluster, along with conformational changes in the presence of pDNA,

4 can contribute for this fact. To achieve similar pDNA condensation degree, an N/P ratio

5 of 5 is needed for RALA/pDNA carriers. At this N/P, higher sized nanoparticles are

6 formed but the zeta potential is comparable to the one obtained for the WRAP5/pDNA

7 optimal point, while the $\mathrm{CC}$ parameter is around $2 \%$ higher. Moreover, the $\mathrm{pH}$ range

8 within physiological conditions is appropriate to promote the formulation of both

9 peptide/pDNA vectors for possible gene delivery applications. If we had to choose a delivery system for further studies on gene delivery, WRAP5/pDNA vectors may conquer special attention. Based on their lower size, along with other favorable properties, these carriers offer great potential for further research.

In general, through the use of experimental design the optimization of RALA-pDNA and WRAP5-pDNA complexes was successfully achieved. The N/P ratios and buffer $\mathrm{pH}$ factors revealed a strong influence in the chosen outputs. It was possible to understand that different peptides present distinct outcomes due to its structural characteristics, as different input ranges were necessary in order to fully take advantage of the design scope.

The development of an adequate vector for gene therapy purposes is still a high demand tool for advances in clinical cancer therapy. Peptide/pDNA based carriers are among the most promising and suitable nano-platforms to operate therapeutically in this field. To further explore their performance as gene delivery vehicles, in this work the optimization of vector formulation step was successfully achieved through the use of experimental design. The choice of buffer $\mathrm{pH}$ and N/P ratio as DoE inputs for the formulation of peptide-pDNA complexes was proven fruitful, allowing the achievement of great nanoparticle features for each peptide, such as, the vector size, zeta potential and pDNA complexation capacity, with a small set of assays. The applied CCF models were statistically significant ( $\mathrm{p}$-value $<0.05$ ), fitted the data and were validated. The chosen inputs presented strong interactions and significant influence towards each output. The 
optimal point for RALA peptide allowed to formulate nanoparticles with size of 183.8 $\mathrm{nm}$, zeta potential of $+32.7 \mathrm{mV}$ and CC of $92.7 \%$. On the other hand, WRAP5 optimal point demonstrated nanoparticles size of $103.0 \mathrm{~nm}$, zeta potential of $+33.6 \mathrm{mV}$ and $\mathrm{CC}$ of $89.5 \%$. Such accomplishment highlights the utility of experimental design tools in the fast and efficient optimization of the peptide/pDNA vectors formulation, what may greatly contribute for deeper research on the development of efficient gene delivery systems.

\section{Acknowledgements}

D. Costa acknowledges the FCT program contract IF/01459/2015 supported by Fundo Social Europeu e Programa Operacional Potencial Humano and A.M. Almeida acknowledges a doctoral fellowship (SFRH/BD/102284/2014) from FCT. P. Boisguerin acknowledges the "Fondation ARC pour la recherché sur le cancer" (PJA2017120617) for financial support. This work was supported by FCT - Foundation for Science and Technology (project FCOMP-01-0124-FEDER-041068 and FEDER funds through the POCI - COMPETE 2020 - Operational Program Competitiveness and Internationalisation in Axis I - Strengthening research, technological development and innovation (Project POCI-01-0145-FEDER-007491) and FCT - Foundation for Science and Technology (Project UID/Multi /00709/2013). This work was also partially supported by "Programa Operacional do Centro, Centro 2020" through the funding of the ICON Project (Interdisciplinary Challenges on Neurodegeneration; CENTRO-01-0145-FEDER000013)".

\section{References}

[1] Yoshizumi, T.; Oikawa, K.; Chuah, J. A.; Kodama, Y.; Numata, K. Selective gene delivery for integrating exogenous DNA into plastid and mitochondrial genomes using peptide-DNA complexes. Biomacromolecules 2018, 19, 1582-1591.

[2] Li, Z.; Liu, Y.; Huang, X.; Hu, C.; Wang, H.; Yuan, L.; Brash, J. L.; Chen, H. Onestep preparation of gold nanovectors using folate modified polyethylenimine and their use in target-specific gene transfection. Colloids Surf. B 2019, 177, 306-312.

[3] Costa, D.; Valente, A. J. M.; Queiroz, J. A. Stimuli-responsive polyamine-DNA blend nanogels for co-delivery in cancer therapy. Colloids Surf. B 2015, 132, 194-201. 
[4] Costa, D.; Briscoe, W. H.; Queiroz, J. Polyethylenimine coated plasmid DNAsurfactant complexes as potential gene delivery systems. Colloids Surf. B 2015, 133, 156163.

[5] Donnelley, M.; Parsons, D. W. Gene therapy for cystic fibrosis lung disease: overcoming the barriers to translation to the clinic. Front. Pharmacol. 2018, 9, 1381.

[6] Falkenhagen, A.; Joshi, S. Genetic strategies for HIV Treatment and prevention. Mol. Ther. Nucleic Acids 2018, 13, 514-533.

[7] Zhang, Y.; Liu, L.; Lin, L.; Chen, J.; Tian, H.; Chen, X.; Maruyama, A. In-situ dualcrosslinked nanoparticles for tumor targeting gene delivery. Acta Biomater 2017, 65, 349362.

[8] Appelbe, O. K.; Kim, B-K.; Rymut, N.; Wang, J.; Kron, S. J.; Yeo, Y. Radiationenhanced delivery of plasmid DNA to tumors utilizing a novel PEI polyplex. Cancer Gene Ther. 2018, 25, 196-206.

[9] Hinderer, C.; Katz, N.; Buza, E. L.; Dyer, C.; Goode, T.; Bell, P.; Richman, L. K.; Wilson, J. M. Severe toxicity in nonhuman primates and piglets following high-dose intravenous administration of an AVV vector expressing human SMN. Hum. Gen. Ther. 2018, 29, 285-298.

[10] Zhang, C.; Zhang, S.; Zhi, D.; Cui, J. Cancer treatment with liposomes based drugs and genes co-delivery systems. Curr. Med. Chem. 2018, 25, 3319-3332.

[11] Rafael, D.; Gener, P.; Andrade, F.; Seras-Franzoso, J.; Montero, S.; Fernández, Y.; Hidalgo, M.; Arango, D.; Sayós, J.; Florindo, H. F.; Abasolo, I.; Schwartz, S.; Videira, M. AKT2 siRNA delivery with amphiphilic-based polymeric micelles show efficacy against cancer stem cells. Drug Deliv. 2018, 25, 961-972.

[12] Somani, S.; Laskar, P.; Altwaijry, N.; Kewcharoenvong, P.; Irving, C.; Robb, G.; Pickard, B. S.; Dufés, C. PEGylation of polypropylenimine dendrimers: effects on cytotoxicity, DNA condensation, gene delivery and expression in cancer cells. Sci. Rep. 2018, 8, 9410.

[13] Jiang, Y.; Huo, S.; Hardie, J.; Liang, X-J.; Rotello, V. M. Progress and perspective of inorganic nanoparticles based siRNA delivery system. Expert Opin. Drug Deliv. 2016, $13,547-559$.

[14] Ali, A. A.; McCrudden, C. M.; McCaffrey, J.; McBride, J. W.; Cole, G.; Dunne, N. J.; Robson, T.; Kissenpfennig, A.; Donnelly, R. F.; McCarthy, H. O. DNA vaccination for cervical cancer; a novel technology platform of RALA mediated gene delivery via polymeric microneedles. Nanomedicine: NBM, 2017, 13, 921-932.

[15] Konate, K.; Dussot, M.; Aldrian, G.; Vaissière, A.; Viguier, V.; Neira, I. F.; Couillaud, F.; Vivès, E.; Boisguerin, P.; Deshayes, S. Peptide-based nanoparticles to 
rapidly and efficiently "Wrap 'n Roll” siRNA into cells. Bioconjugate Chem. 2019, 30, 592-603.

3

4

[16] Costa, D.; Albuquerque, T.; Queiroz, J. A.; Valente, A. J. M. A co-delivery platform based on plasmid DNA peptide-surfactant complexes: formation, characterization and release behaviour. Colloids Surf. B 2019, 178, 430-438.

[17] de Raad, M.; Teunissen, E. A.; Mastrobattista, E. Peptide vectors for gene delivery: from single peptides to multifunctional peptide nanocarriers. Nanomedicine 2014, 9, 2217-2232.

[18] Hoyer, J.; Neundorf, I. Peptide vectors for the Nonviral delivery of nucleic acids. Acc. Chem. Res. 2012, 45, 1048-1056.

[19] Li, M.; Tao, Y.; Shu, Y.; LaRochelle, J. R.; Steinauer, A.; Thompson, D.; Schepartz, A.; Chen, Z-Y.; Liu, D. R. Discovery and characterization of a peptide that enhances endosomal escape of delivered proteins in vitro and in vivo. J. Am. Chem. Soc. 2015, 137, 14084-14093.

[20] Khondee, S.; Baoum, A.; Siahaan, T. J.; Berkland, C. Calcium condensed LABLTAT complexes effectively target gene delivery to ICAM-1 expressing cells. Mol. Pharmaceutics 2011, 8, 788-798.

[21] Ahmad, A.; Ranjan, S.; Zhang, W.; Zou, J.; Pyykkö, I.; Kinnunen, P. K. J. Novel endosomolytic peptides for enhancing gene delivery in nanoparticles. Biochim. Biophys. Acta 2015, 1848, 544-553.

[22] Letho, T.; Ezzat, K.; Wood, M. J. A.; El Andaloussi, S. Peptides for nucleic acid delivery. Adv. Drug Delivery Rev. 2016, 106, 172.

[23] Jeong, C.; Yoo, J.; Lee, D.; Kim, Y-C. A branched TAT cell-penetrating peptide as a novel delivery carrier for the efficient gene transfection. Biomater. Res. 2016, 20, 228235 .

[24] Tai, W.; Gao, X.; Functional peptides for siRNA delivery. Adv. Drug Deliv. Rev. 2017, 110, 157-168.

[25] Chen, J.; Guan, X.; Hu, Y.; Tian, H.; Chen, X. Peptide-based and polypeptide-based gene delivery systems. Top Curr. Chem. 2017, Z, 375:32.

[26] Hao, X. F.; Li, Q.; Guo, J. T.; Ren, X. K.; Feng, Y. K.; Shi, C. C.; Zhang, W. C. Multifunctional gene carriers with enhanced specific penetration and nucleus accumulation to promote neovascularization of HUVECs in vivo. ACS Appl. Mater. Interfaces 2017, 9, 35613-35627.

[27] Kang, Z.; Meng, Q.; Liu, K. Peptide-based gene delivery vectors. J. Mater. Chem. B 2019, 7, 1824-1841.

[28] Clogston, J. D.; Patri, A. K. Methods in Molecular Biology 2011 vol. 697, Springer Science Business Media, LLC. Scott E. McNeil (Ed.). Characterization of nanoparticles intended for drug delivery. 
[29] Liu, X.; Wu, F.; Tian, Y.; Wu, M.; Zhou, Q.; Jiang, S.; Niu, Z. Size dependent cellular uptake of rod-like bionanoparticles with different aspect ratios. Sci. Rep. 2016, 6, 24567.

[30] Eriksson, L.; Johansson, E.; Wold, N. K.; Wikstrom, C. Design of experiments : Principles and Applications. Umetrics Academy 2008.

[31] Myers, J. L.; Well, A.; Lorch, R. F. Research design and statistical analysis (3 ${ }^{\text {rd }}$ ed.) 2010, New York, NY:Routledge.

[32] Almeida, A. M.; Queiroz, J. A.; Sousa, F.; Sousa, A. Optimization of supercoiled HPV-16 E6/E7 plasmid DNA purification with arginine monolith using design of experiments. J Chromatogr B Anal Technol Biomed Life Sci 2015, 978, 145-150.

[33] Kwok, A.; McCarthy, D.; Hart, S. L.; Tagalakis, A. D. Systematic comparisons of formulations of linear oligolysine peptides with siRNA and plasmid DNA. Chem. Biol. Drug Des. 2016, 87, 747-763.

[34] Jain, A. K.; Massey, A.; Yusuf, H.; McDonald, D. M.; McCarthy, H. O.; Kett, V. L. Development of polymeric-cationic peptide composite nanoparticles, a nanoparticle-innanoparticle system for controlled gene delivery. Int. J. Nanomedicine 2015, 10, 71837196.

[35] Karimi, M.; Avci, P.; Ahi, M.; Gazori, T.; Hamblin, M. R.; Naderi-Manesh, H. Evaluation of Chitosan-Tripolyphosphate Nanoparticles as a p-shRNA Delivery Vector: Formulation, Optimization and Cellular Uptake Study. J. Nanopharm. Drug Deliv. 2013, 1, 266-278.

[36] Ferreira, S.; Duarte, A. P.; Ribeiro, M. H. L.; Queiroz, J. A; Domingues, F. C. Response surface optimization of enzymatic hydrolysis of Cistus ladanifer and Cytisus striatus for bioethanol production. Biochem. Eng. J. 2009, 45, 192-200.

[37] Hunter, E. A.; Haaland, P. D. Experimental design in Biotechnology. 2006, CRC Press.

[38] Gelman, A. Analysis of variance - why it is more important than ever. Ann. Statist. 2005, 33, 1-53.

[39] Costa, D.; Valente, A. J. M.; Queiroz, J. A.; Sousa, Â. Finding the ideal polyethylenimine-plasmid DNA system for co-delivery of payloads in cancer therapy. Colloids Surf. B 2018, 170, 627-636.

[40] Yoo, J.; Cui, Q. Does arginine remain protonated in the lipid membrane? Insights from microscopic pKa calculations. Biophys. J. 2008, 94, 61-63.

[41] Fitch, C. A.; Platzer, G.; Okon, M.; Garcia-Moreno, B. E.; McIntosh, L. P. Arginine: its pKa value revisited. Protein Sci. 2015, 24, 752-761.

[42] Harms, M. J.; Schlessman, J. L.; Sue, G. R.; Garcia-Moreno, B. Arginine residues at internal positions in a protein are always charged. Proc. Natl. Acad. Sci. USA 2011, 108, 18954-18959. 
1 [43] Isom, D. G.; Castaneda, C. A.; Cannon, B. R.; Garcia-Moreno, B. E. Large shifts in 2 pKa values of lysine residues buried inside a protein. Proc. Natl. Acad. Sci. USA 2011, $3108,5260-5265$.

4 [44] McCarthy, H. O.; McCaffrey, J.; McCrudden, C. M.; Zholobenko, A.; Ali, A. A.; 5 McBride, J. W.; Massey. A. S.; Pentlavalli, S.; Chen, K-H.; Cole, G.; Loughran, S. P.; 6 Dunne, N. J.; Donnelly, R. F.; Kett, V. L.; Robson, T. Journal of Control Rel. 2014, 189, 7 141-149.

8 [45] Patil S. A.; Surwase, S. N.; Jadhav S. B.; Jadhav J. P. Optimization of medium using 9 response surface methodology for l-DOPA production by Pseudomonas sp. SSA. 10 Biochem Eng $J$ 2013, 74, 36-45. 
A

\section{Plasmid complexation at different charge ratios}

\section{Peptide}

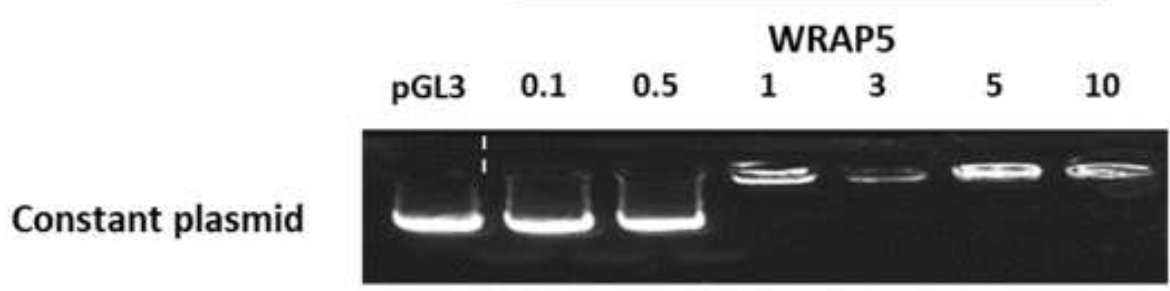

B

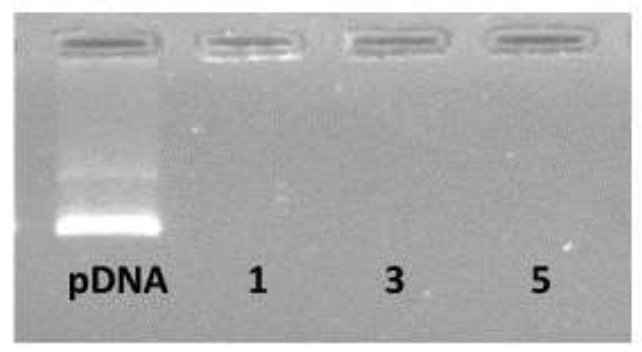

C

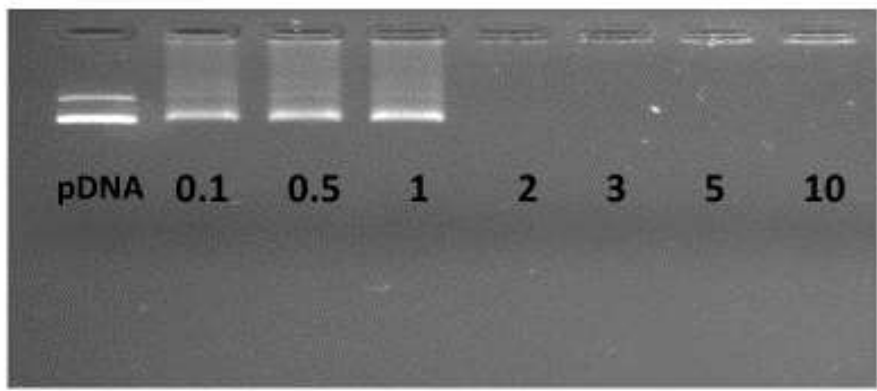

4 Figure 1. Analysis of peptide/pDNA complexation behaviour through agarose gel 5 electrophoresis for WRAP5/pGL3 (A), WRAP5/p53 (B) and RALA/p53 (C) at several 6 N/P ratios (indicated in each figure). The samples were loaded at the application site at 7 the upper end of the image and the lower end is the cathodic end. 

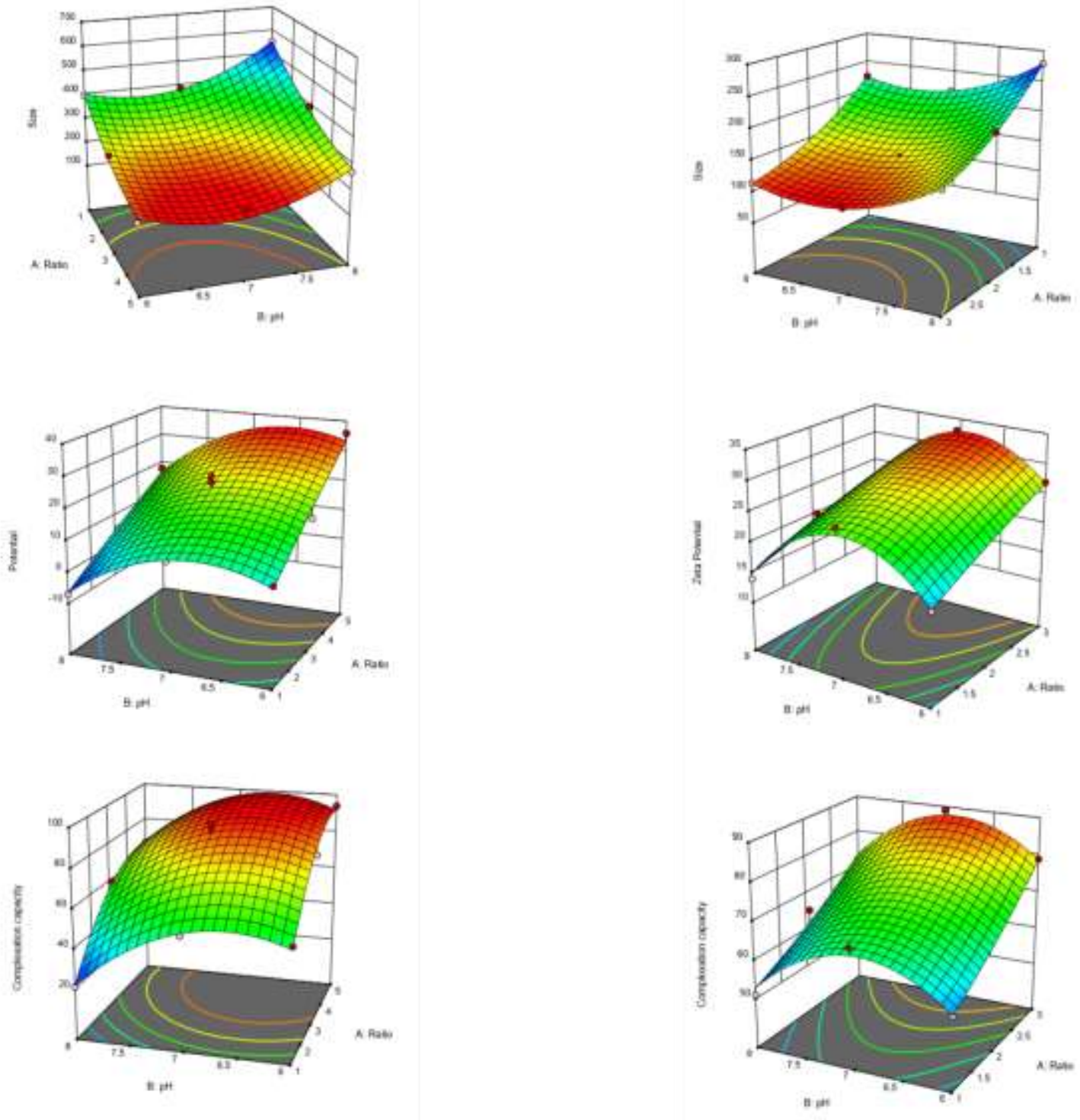

1

2 Figure 2. Surface plots of size (A), zeta potential (B) and complexation capacity (C) 3 responses for RALA peptide and size (D), zeta potential (E) and complexation capacity 4 (F) responses for WRAP5 peptide. 
1 Table 1 - Three-level CCF design used throughout this study.

\begin{tabular}{ccc}
\hline $\begin{array}{c}\text { Number of } \\
\text { Experiments }\end{array}$ & N/P ratio & Buffer $\mathrm{pH}$ \\
\hline 1 & 0.000 & 0.000 \\
2 & -1.000 & 1.000 \\
3 & 0.000 & -1.000 \\
4 & 1.000 & 1.000 \\
5 & 0.000 & 1.000 \\
6 & 1.000 & 0.000 \\
7 & -1.000 & 0.000 \\
8 & -1.000 & -1.000 \\
11 & 0.000 & 0.000 \\
9 & 1.000 & -1.000 \\
10 & 0.000 & 0.000 \\
\hline & &
\end{tabular}


1 Table 2 - RALA and WRAP5 central composite design matrix and response values for 2 nanoparticle size and zeta potential determined by DLS, and complexation capacity (CC).

\begin{tabular}{|c|c|c|c|c|c|c|c|c|c|c|}
\hline \multirow[b]{2}{*}{$\begin{array}{l}\text { Number } \\
\text { of Runs }\end{array}$} & \multicolumn{5}{|c|}{ RALA } & \multicolumn{5}{|c|}{ WRAP5 } \\
\hline & $\mathrm{N} / \mathrm{P}$ & $\begin{array}{c}\text { Buffer } \\
\mathrm{pH}\end{array}$ & $\begin{array}{l}\text { Size } \\
(\mathrm{nm})\end{array}$ & $\begin{array}{c}\text { Zeta } \\
\text { Potential } \\
(\mathrm{mV})\end{array}$ & $\mathrm{CC}(\%)$ & $\mathrm{N} / \mathrm{P}$ & $\begin{array}{c}\text { Buffer } \\
\text { pH }\end{array}$ & $\begin{array}{l}\text { Size } \\
(\mathrm{nm})\end{array}$ & $\begin{array}{c}\text { Zeta } \\
\text { Potential } \\
(\mathrm{mV})\end{array}$ & $\mathrm{CC}(\%)$ \\
\hline 1 & 5 & 8 & 271 & 18 & 67 & 2 & 7 & 141 & 29 & 73 \\
\hline 2 & 3 & 7 & 203 & 26 & 86 & 1 & 8 & 279 & 14 & 51 \\
\hline 3 & 5 & 6 & 183 & 36 & 94 & 2 & 6 & 158 & 23 & 69 \\
\hline 4 & 3 & 7 & 220 & 24 & 90 & 3 & 8 & 157 & 21 & 72 \\
\hline 5 & 3 & 6 & 287 & 16 & 81 & 2 & 8 & 202 & 20 & 65 \\
\hline 6 & 3 & 7 & 223 & 20 & 93 & 3 & 7 & 102 & 33 & 89 \\
\hline 7 & 3 & 8 & 394 & 5 & 59 & 1 & 7 & 216 & 26 & 68 \\
\hline 8 & 1 & 6 & 401 & 5 & 52 & 1 & 6 & 225 & 17 & 56 \\
\hline 9 & 1 & 8 & 554 & -7 & 21 & 2 & 7 & 141 & 29 & 75 \\
\hline 10 & 1 & 7 & 389 & 8 & 52 & 3 & 6 & 116 & 27 & 79 \\
\hline 11 & 5 & 7 & 178 & 31 & 95 & 2 & 7 & 140 & 28 & 75 \\
\hline
\end{tabular}


1 Table 3 - Statistical coefficients of RALA and WRAP5 models. CC-Complexation

2 Capacity.

3

\begin{tabular}{|c|c|c|c|c|c|c|c|c|}
\hline \multirow{2}{*}{ Output } & \multicolumn{4}{|c|}{ RALA } & \multicolumn{4}{|c|}{ WRAP5 } \\
\hline & $\mathbf{R}^{2}$ & $\begin{array}{c}\text { Adjusted } \\
\mathbf{R}^{2}\end{array}$ & $\begin{array}{c}\text { Predicted } \\
\mathbf{R}^{\mathbf{2}}\end{array}$ & $\begin{array}{c}\text { Adeq } \\
\text { Precision }\end{array}$ & $\mathbf{R}^{2}$ & $\begin{array}{c}\text { Adjusted } \\
\mathbf{R}^{2}\end{array}$ & $\begin{array}{c}\text { Predicted } \\
\qquad \mathbf{R}^{\mathbf{2}}\end{array}$ & $\begin{array}{c}\text { Adeq } \\
\text { Precision }\end{array}$ \\
\hline Size & 0.9802 & 0.9605 & 0.8592 & 23.1927 & 0.9994 & 0.9989 & 0.9957 & 135.0557 \\
\hline $\begin{array}{c}\text { Zeta } \\
\text { Potential }\end{array}$ & 0.9649 & 0.9297 & 0.7869 & 16.4130 & 0.9814 & 0.9582 & 0.7859 & 18.5120 \\
\hline $\mathrm{CC}$ & 0.9902 & 0.9805 & 0.9443 & 30.6801 & 0.9741 & 0.9418 & 0.7630 & 16.9626 \\
\hline
\end{tabular}


1 Table 4 - ANOVA analysis for RALA and WRAP5. P-value $<0.05$ is considered significant. CC-Complexation Capacity.

\begin{tabular}{|c|c|c|c|c|c|c|c|c|c|c|c|c|c|}
\hline \multicolumn{7}{|c|}{ RALA } & \multicolumn{7}{|c|}{ WRAP5 } \\
\hline Output & Source & $\begin{array}{l}\text { Sum of } \\
\text { Squares }\end{array}$ & df & $\begin{array}{l}\text { Mean } \\
\text { Square }\end{array}$ & F-value & p-value & Output & Source & $\begin{array}{l}\text { Sum of } \\
\text { Squares }\end{array}$ & df & $\begin{array}{l}\text { Mean } \\
\text { Square }\end{array}$ & F-value & p-value \\
\hline \multirow{2}{*}{ Size } & Model & $1.400 \mathrm{E}+05$ & 5 & 27994.09 & 49.57 & 0.0003 & \multirow{2}{*}{ Size } & Model & 28460.51 & 5 & 5692.10 & 1775.38 & $<0.0001$ \\
\hline & $\begin{array}{l}\text { Lack of } \\
\text { Fit }\end{array}$ & 2591.05 & 3 & 863.68 & 7.42 & 0.1210 & & $\begin{array}{l}\text { Lack of } \\
\text { Fit }\end{array}$ & 15.36 & 3 & 5.12 & 15.36 & 0.0617 \\
\hline \multirow{2}{*}{$\begin{array}{c}\text { Zeta } \\
\text { Potential }\end{array}$} & Model & 1583.06 & 5 & 316.61 & 27.45 & 0.0012 & \multirow{2}{*}{$\begin{array}{c}\text { Zeta } \\
\text { Potential }\end{array}$} & Model & 326.22 & 5 & 65.24 & 42.24 & 0.0015 \\
\hline & $\begin{array}{l}\text { Lack of } \\
\text { Fit }\end{array}$ & 39.00 & 3 & 13.00 & 1.39 & 0.4438 & & $\begin{array}{l}\text { Lack of } \\
\text { Fit }\end{array}$ & 5.51 & 2 & 2.76 & 8.27 & 0.1079 \\
\hline \multirow{2}{*}{$\mathrm{CC}$} & Model & 5594.55 & 5 & 1118.91 & 101.56 & $<0.0001$ & \multirow{2}{*}{$\mathrm{CC}$} & Model & 1061.91 & 5 & 212.38 & 30.14 & 0.0029 \\
\hline & $\begin{array}{c}\text { Lack of } \\
\text { Fit }\end{array}$ & 30.42 & 3 & 10.14 & 0.8222 & 0.5896 & & $\begin{array}{l}\text { Lack of } \\
\text { Fit }\end{array}$ & 25.52 & 2 & 12.76 & 9.57 & 0.0946 \\
\hline
\end{tabular}


1 Table 5 - Coded multiple regression equation for size, zeta-potential and complexation

2 capacity (CC) of RALA and WRAP5. A - N/P Ratio; B - Buffer pH

\begin{tabular}{c|c|c}
\hline Output & RALA & WRAP5 \\
\hline \multirow{2}{*}{ Size } & $+227.21-118.67 \mathrm{~A}+58.00 \mathrm{~B}-16.25 \mathrm{AB}+$ & $+141.00-57.50 \mathrm{~A}+23.17 \mathrm{~B}-3.25 \mathrm{AB}+$ \\
& $38.47 \mathrm{~A}^{2}+95.47 \mathrm{~B}^{2}$ & $16.18 \mathrm{~A}^{2}+37.18 \mathrm{~B}^{2}$ \\
\hline Zeta & $+22.00+13.17 \mathrm{~A}-6.83 \mathrm{~B}-1.50 \mathrm{AB}-0.5000$ & $+29.14+4.00 \mathrm{~A}-1.89 \mathrm{~B}-0.7500 \mathrm{AB}-$ \\
Potential & $\mathrm{A}^{2}-9.50 \mathrm{~B}^{2}$ & $0.3571 \mathrm{~A}^{2}-8.68 \mathrm{~B}^{2}$ \\
\hline CC & $+88.68+21.83 \mathrm{~A}-13.33 \mathrm{~B}+1.00 \mathrm{AB}-13.71$ & $+75.43+10.83 \mathrm{~A}-2.18 \mathrm{~B}-0.5000 \mathrm{AB}+1.43$ \\
& $\mathrm{~A}^{2}-17.21 \mathrm{~B}^{2}$ & $\mathrm{~A}^{2}-11.54 \mathrm{~B}^{2}$ \\
\hline
\end{tabular}

4 
1 Table 6 - Predicted outputs for optimal point. CC-Complexation Capacity. CI-Confidence

2 Interval.

\begin{tabular}{cccc|cccc}
\hline \multicolumn{2}{c}{ RALA } & \multicolumn{5}{c}{ WRAP5 } \\
\hline Output & $\begin{array}{c}\text { Predicted } \\
\text { mean }\end{array}$ & $\begin{array}{c}\text { 95\% CI low } \\
\text { for Mean }\end{array}$ & $\begin{array}{c}\text { 95\% CI high } \\
\text { for Mean }\end{array}$ & Output & $\begin{array}{c}\text { Predicted } \\
\text { mean }\end{array}$ & $\begin{array}{c}\text { 95\% CI low } \\
\text { for Mean }\end{array}$ & $\begin{array}{c}\text { 95\% CI high } \\
\text { for Mean }\end{array}$ \\
Size & 145.59 & 102.34 & 188.85 & Size & 101.90 & 98.62 & 105.18 \\
$\begin{array}{c}\text { Zeta } \\
\text { Potential }\end{array}$ & 36.48 & 30.30 & 42.66 & $\begin{array}{c}\text { Zeta } \\
\text { Potential }\end{array}$ & 32.43 & 30.36 & 34.50 \\
CC & 98.99 & 92.95 & 105.03 & CC & 86.93 & 82.27 & 91.60 \\
\hline
\end{tabular}

3 